\title{
Representaciones literarias de la figura de Laureano Gómez
}

E n este capítulo se analizará la figura de Laureano Gómez a partir de la Guerra Fría, la difusión de dicho discurso y las respuestas que surgieron a partir de la literatura. Para ello, se tomó la novela gráfica La gran mancha roja, de la cual no se conoce el autor, La metamorfosis de Su Excelencia, de Jorge Zalamea, y Viento seco, de Daniel Caicedo.

Para contextualizar los antecedentes del Bogotazo, nos remitimos al estudio del historiador Gonzalo Sánchez, quien afirma que al finalizar "la Segunda Guerra Mundial, Colombia seguía teniendo, básicamente, una estructura oligárquica, cuestionada insistentemente en las dos décadas procedentes, pero no seriamente amenazada" (1989, p. 127). Este contexto internacional, sin duda, impactó a Colombia, y contribuyó de manera política y discursiva a reforzar el discurso de nación y a la creación de un enemigo.

En este sentido, es necesario tener en cuenta que para 1948 el presidente era Mariano Ospina, y Laureano Gómez era ministro de Relaciones Exteriores y candidato por el Partido Conservador a las elecciones presidenciales que se aproximaban. Jorge Eliécer Gaitán era el candidato del Partido Liberal.

La inminencia del triunfo de Gaitán, más que previsible era un hecho, alarmó a la oligarquía conservadora, que echó mano del lenguaje de la Guerra Fría para describir a Gaitán como la punta de lanza del comunismo y, por consiguiente, como el representante de oscuras fuerzas destructoras de la libre empresa y de los valores cristianos occidentales (Sánchez, 1989, p. 127). 
Tras el asesinato de Gaitán, los discursos en torno al comunismo se iban acrecentando en expresiones como "bandolero", "populacho" y "revoltoso", todo debido al "fantasma del comunismo", entre otros términos en los cuales se profundizará más adelante. No se entrará en la discusión de la expresión "caudillo del pueblo" que se le ha adjudicado a Gaitán, pero es necesario tener en cuenta que tenía una fuerza opositora muy importante al Gobierno conservador y se basaba en afianzar las reformas, especialmente la de tierras al tener un contacto directo con el pueblo.

La discusión, insistimos, no es revisar las tensiones políticas de la época entre Laureano Gómez como sucesor de Ospina, ni quedarse en el asesinato de Gaitán, sino comprender que, tras su muerte, el país tomó una postura política a través de los discursos difundidos por Ospina y Gómez. La oportunidad política fue aprovechada a partir de una interpretación ideológica con el fin de deslegitimar las respuestas reivindicatorias de las masas populares frente a dicho asesinato.

Uno de los discursos más recurrentes fue el de "reestablecer el orden" debido a la represión estatal, y los calificativos usados para referirse al 9 de abril como "el día de la abominación”, "el día que debe ser borrado de la historia”, "la amenaza al buen nombre del país” fueron los más usados y se explicarán a continuación. Por un lado,

el presidente Ospina pensaba que el origen del problema había que buscarlo más allá del bipartidismo, es decir, en uno de los terrenos forzosamente nocivos para el país y su bandera discursiva estuvo basada en la Patria, en palabras de dicho expresidente: “... ya no es del Partido Conservador ni del Partido Liberal sino de tremenda amenaza a las instituciones básicas de la vida, honra y bienes de los asociados" (Arias, 1998, p. 4).

Por otro lado, el autor evidencia que Laureano Gómez también hizo énfasis en mantener este discurso, casi tres años después de los hechos enfatizaba en que "la tarea central de su gobierno consistía en la reconquista de la tranquilidad pública perturbada tan profundamente como consecuencia de la subversión del 9 de abril" (Arias, 1998, p. 3), a pesar de que: 
La Junta Revolucionaria de la capital fue tímida. Llegó a plantearse el problema del poder [...] pero no tuvo capacidad o vocación de poder [...], su salida después de un memorable trasnocho, la noticia transmitida, desde las emisoras, controladas ahora por el gobierno, fue: se revive la Unión Nacional, y Echandía, el representante de la oligarquía más cercana a Gaitán, es el nuevo ministro de Gobierno. Por su parte, Lleras Restrepo, uno de los más encarnizados adversarios de Gaitán, presidiría los funerales el 21 de abril. También la oligarquía estaría en el entierro (Sánchez, 1989, p. 135).

Estos discursos estaban basados en la moral y en la religión y se difundían a través de los medios de comunicación como el periódico $E l$ Siglo, que publicó en 1950 el editorial "El día de la abominación", en el que afirma: "El 9 de abril aún no ha concluido. Esa ola de bandolerismo que ha asolado al país en estos cinco años es fruto consecuencial de esta fecha" (El Siglo, citado en Arias, 1998, p. 3). No solo se le atribuye al 9 de abril la responsabilidad de la violencia, sino que se crea un enemigo y una lectura del otro, con el apoyo del discurso de la Iglesia porque el clero también sentó una postura a favor del Estado.

Es necesario destacar que pese a lo acontecido, se le atribuyó al Bogotazo el inicio de la violencia en Colombia. Arias muestra un panorama distinto antes del suceso, pero le atribuye a ese hecho histórico el lenguaje de la violencia y de la creación de una "ola de terror" frente a quien pensara diferente a las ideologías políticas de la época, como se mencionó antes. Este panorama político evidentemente impactó en las prácticas, ya que el aparato estatal se concentraba en diversos modus operandi que contribuyeron a que la persecución y la materialidad del bipartidismo no se agotaran, sino que se reforzaran.

Asimismo, la relación de estos hechos con Gómez es clara, según Sánchez:

Laureano Gómez, político aguerrido, brillante y sectario, atiza la confrontación partidista, capta a los terratenientes amenazados o golpeados en las más recienten movilizaciones campesinas, ofrece garantías de acumulación a los capitalistas más asustados que ven en el lenguaje redistributivo de Gaitán un disimulado programa 
socialista y, sobre todo, enardece los ánimos de las zonas rurales en donde a la cultivada mentalidad de sumisión secular se agrega el control social y político de la Iglesia (Sánchez, 1989, p. 131).

A continuación, abordaremos tres aspectos fundamentales: el primero son los discursos representados en las imágenes y el texto del cómic corto La gran mancha roja. En segundo lugar, se analizarán representaciones de la figura de Laureano Gómez en la novela Viento seco, las formas discursivas implementadas en la época en el territorio vallecaucano, los modus operandi de los victimarios y las formas de la violencia que se configuraron en la masacre de Ceilán y en la masacre de la Casa Liberal. Por último, se revisa La metamorfosis de Su Excelencia, como una respuesta a las presiones de la época.

\section{Análisis contextual del cómic La gran mancha roja}

Este texto fue publicado por la Editorial Bogotá, tiene 102 ilustraciones a blanco y negro acompañadas de textos cortos, escritos a máquina, y se apoya en fragmentos de discursos de diferentes personajes políticos de la época, como Augusto Ramírez Moreno, Rafael Bernal Jiménez, Guillermo León Valencia, Joaquín Estrada Monsalve, Enrique Santos, Mariano Ospina, Laureano Gómez, Jose María Villarreal y Luis Eduardo Nieto Caballero, y obispos en representación de la Iglesia católica, así como los medios de comunicación El Tiempo y Semana. Por último, resalta apartados de libros y los discursos cortos e imágenes de otros actores como Carlos H. Pareja, Eduardo Zalamea Borda, Joaquín Tiberio Galvis y Rómulo Guzmán.

En conjunto esta obra encierra una serie de aristas complejas. En su forma tiene dos maneras de expresión que la componen y le permiten enfatizar con contundencia que su interés es contribuir a la historia oficial, pero con un estilo comunicativo concreto que le sirve para sintetizar información y al mismo tiempo no concluir en otra historia. Este aspecto se abordará en el análisis general de la obra. El argumento reiterativo en la historieta es señalar al comunismo como responsable de estos hechos. Arias expresa: 
El autor de La Gran Mancha Roja insiste de sobremanera, desde el comienzo hasta el final, en el mismo argumento. Sin embargo, las imágenes y el texto de esta historieta suministran otro tipo de información acerca de los responsables, lo que permite tener una idea más clara de los "revoltosos"; este tipo de precisiones resulta valiosísimas para entender la imagen que hace el autor del "culpable” (Arias, 1998, p. 4).

En este contexto es necesario recalcar que es posible estudiar en este cómic tanto las formas discursivas del otro como las lecturas intrínsecas en el lenguaje escrito en relación con la imagen.

\section{Resumen de la historia}

La historieta empieza con un el título "Para la eterna memoria", en la que esta se cataloga como una síntesis que:

... encierra la trascendente gravedad de un delito colectivo que no tiene paralelo en los 138 años de nuestra existencia republicana. Y aun cuando las necesidades de la pacificación del país y la recuperación de la autoridad, impusieran una ley de amnistía, los horrendos crímenes que en esos nefandos días se "cometieron" jamás podrán ser olvidados por la república y permanecerán latentes en el recuerdo horrorizado de muchas generaciones. Sobre las transacciones de la política, la moral inmutable tiene ya dado su fallo inapelable y la conciencia, Supremo Juez, al señalar a los responsables de la semana roja de Colombia, afianzará el orden jurídico que nos protege y sin cuyo amparo la sociedad indefensa perecería irremisiblemente.

Esta breve y dramática serie de episodios servirá también para que la historia se escriba sobre la verdad y sin adulteraciones del interés político. Eminentes colombianos de todos los partidos deponen con sus palabras en este proceso y los autores de máximos delitos contra el régimen constitucional y la seguridad del Estado, devastación, incendios, saqueos, homicidios y sacrilegios, también concurren en efigie, para ser condenados por la opinión imparcial sobre el testimonio de sus propias palabras. 
A mantener viva la conciencia social, y como ejemplar admonición de vigilancia y defensa contra hechos que no volverán a repetirse, si sabemos tenerlos presentes, va esta historia gráfica de la Gran Mancha Roja del 9 de abril de 1948. Publicación de la Central Informativa Colombiana-Cenic (Historia Crítica, 1998, p. 8).

Esta introducción demuestra que la intención de la historieta es divulgar y reafirmar la historia oficial, sin embargo, es necesario detenerse en los aspectos discursivos de la época y en la difusión de los mensajes tanto de derecha como de izquierda, esto en contraste con el contexto anteriormente mencionado.

La primera parte de la historia empieza a representar la importancia de la IX Conferencia Panamaricana y muestra imágenes de la ciudad el 1 de abril de 1948. Posteriormente, aparece la imagen de Jorge Eliécer Gaitán y otra de su asesinato, lo cual evidencia la clásica historia del personaje que le disparó: Juan Roa Sierra. En contraste con ello, muestra las reacciones y agresiones que desencadenaron este hecho, y las formas de difundir la revolución, materializada en el vandalismo, para lo cual los revoltosos asaltaron las ferreterías con el fin de atacar los espacios de referencia más importantes como el periódico conservador El Siglo, la casa de Laureano Gómez en Torcoroma y el edificio García Cadena. También plasma ataques a vehículos particulares. Continúa mostrando imágenes de lo que sucede en las calles hasta que la población llega al Capitolio Nacional.

Por otro lado, muestra a la Policía y al Ejército, que intentan controlar a la gente; en las ilustraciones se ve la forma como se ubican en el espacio tanto la población como la fuerza militar. Posteriormente, otros lugares son afectados ante estos enfrentamientos, como el Palacio de Justicia y el Palacio de Comunicaciones.

Ante este panorama, el autor insiste en que el presidente, Mariano Ospina, permanece sereno. Se reúnen los ministros del Despacho Ejecutivo, los altos jefes y los jefes superiores del Ejército, quienes cumplieron las órdenes del presidente; el autor describe a Ospina como el "supremo comandante de las Fuerzas Armadas". Asimismo, en contraste con estas imágenes ilustra a los liberales que exigían la renuncia de Ospina y aclaran que no han recibido apoyo estatal. En relación con 
esta imagen aparece una frase atribuida a Ospina: "Más vale un presidente asesinado que un presidente fugitivo" (ilustración n. ${ }^{\circ}$ 59, p. 19). El liberalismo y el Partido Conservador formaron la Unión Nacional con la idea de la salvación de la república.

Posteriormente, las ilustraciones evidencian que los asaltos también afectan al Palacio Arzobispal Primado de Colombia, con el argumento de la alianza atea, y muestra la postura de monseñor Ismael Perdomo frente a los hechos. El autor continúa ilustrando los saqueos y toma una cita que complementa el discurso en busca de culpar al comunista y centrar a la población en dicho aspecto:

$$
\begin{aligned}
& \text { ¿por qué lo han hecho? Si como probará, el criminal [Roa Sierra] } \\
& \text { fue instrumento de los comunistas al liberalismo le queda una con- } \\
& \text { signa: A LA CARGA CONTRA EL COMUNISMO, ASESINO DE } \\
& \text { GAITÁN Y DESTRUCTOR DE LA REPÚBLICA” (El Tiempo, } \\
& \text { 1948, citado en La gran mancha roja). }
\end{aligned}
$$

Otros lugares fueron asaltados: el Ministerio de Gobierno, el Palacio de la Nunciatura, la Universidad Femenina Javeriana y otros lugares religiosos emblemáticos. La revista Semana a través de Hernando Téllez, en el apartado titulado: Terror y vergüenza, hace una crítica de por qué no asaltaron el Teatro Colón y sí a estos lugares (Semana, citada en La gran mancha roja, p. 22).

La narración salta en el tiempo al 10 de abril de 1948 y pone en evidencia que aún grupos militares rodeaban los escombros de la ciudad con el fin de mantener el orden. Asimismo, desde Boyacá el gobernador Villarreal había enviado tropas a Bogotá, así como el gobernador de Nariño, que "llegaban a tiempo para salvar la república..." (La gran mancha roja, ilustración 82, p. 24).

... pero tesoros inmemorables de ella ya se habían perdido para siempre, la misma tea criminal que incendiará el palacio de San Carlos, la Plaza de Bolívar, sede de la Cancillería, quemada también y reducida a escombros, la casa del hotel Regina donde habitó y murió el General Francisco de Paula Santander (La gran mancha roja, ilustraciones 83 y 84 , p. 24). 
En las siguientes ilustraciones cuestionan quién mató a Gaitán, a lo cual responden: "NO FUERON LOS CONSERVADORES” (El Tiempo, citado en La gran mancha roja, p. 24). En los dibujos inmediatamente siguientes se muestra la forma como la fuerza pública actúa desde los tejados de las casas y cerca a la torre Santa Bárbara, usando la estrategia rusa. Tras esta descripción, el autor muestra en las siguientes caricaturas el panorama del 9, 10 y 11 de abril, en contraste con los medios de comunicación. Se le atribuyó la responsabilidad a los comunistas de "sabotear la Conferencia Panamericana". El cómic termina con la narración del crimen de Pedro María Rodríguez en la Plaza de Armero y refuerza una vez más la relación de los hechos del 9 de abril con la figura de la Iglesia.

\section{Análisis de imágenes contundentes de la historia}

En esta parte del documento se tomarán imágenes específicas de la historieta con el fin de analizar cómo el discurso internacional de la Guerra Fría incidió durante el mandato de Ospina, el Bogotazo y la posesión del cargo de presidente de Laureano Gómez. Como primera medida, se busca relacionar las imágenes y el texto del cómic La gran mancha roja con relación a los responsables del "desorden público" y los personajes que utiliza el autor. En segundo lugar, se conectan dichos discursos e imágenes con la figura de Laureano Gómez.

\section{Discursos de lo popular}

El discurso del comunismo es reiterativo en la historieta, así como la forma de atribuir la responsabilidad del asesinato de Gaitán al comunismo, lo cual evidencia que la ideología internacional de la Guerra Fría fue implementada en la época, influía en las prácticas cotidianas y contribuía a dividir la población entre quienes estaban en contra del comunismo, o mejor, a favor del Gobierno, y quienes no lo estaban y por ello recibían el calificativo de "populacho", "bandoleros" o "comunistas”, entre otros adjetivos. 
En el cómic se pueden ver reflejados estos postulados. El discurso de lo popular no distinguía clase ni posición social, por ejemplo, incluía al rector de la Universidad Nacional, en aquel entonces Gerardo Molina, a quien describen en la ilustración número 30 como lo muestra la imagen. También relaciona a otros personajes.

Figura 4. Imágenes 30, 31 y 32 de La gran mancha roja, p. 14.

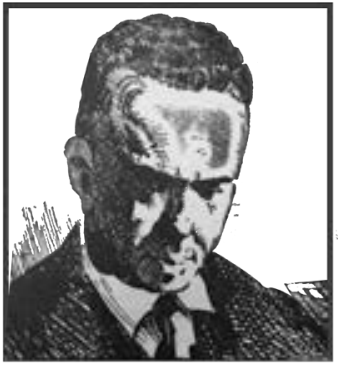

30) El propio Rector de le Universidad Nacional Gerarde Molina, secialista, desde los micrófenes do la radie Nacienea

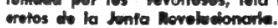

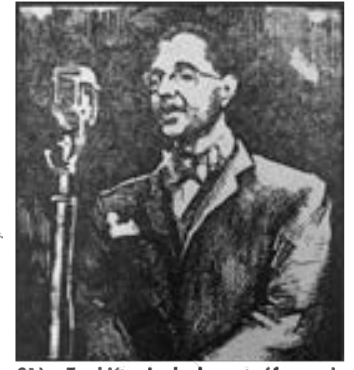
31) Tambiàn deode les micrsfonos de 32) Mientrass gentes de monor mpor-

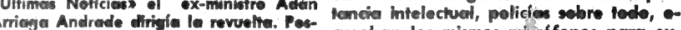

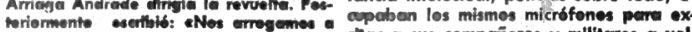

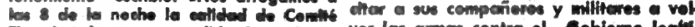



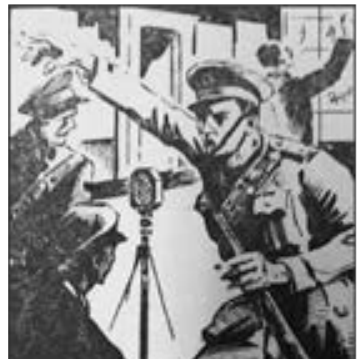
mo.

Por otro lado, el cómic desde el principio reitera que los revoltosos asaltaron los lugares más representativos de la ciudad, que vestían joyas robadas de las tiendas y que prendieron fuego a las ferreterías. En la imagen número 43 se evidencia la relación que establece el autor entre los prisioneros y los "revoltosos".

Figura 5. Imagen 43 de La gran mancha roja, p. 16.

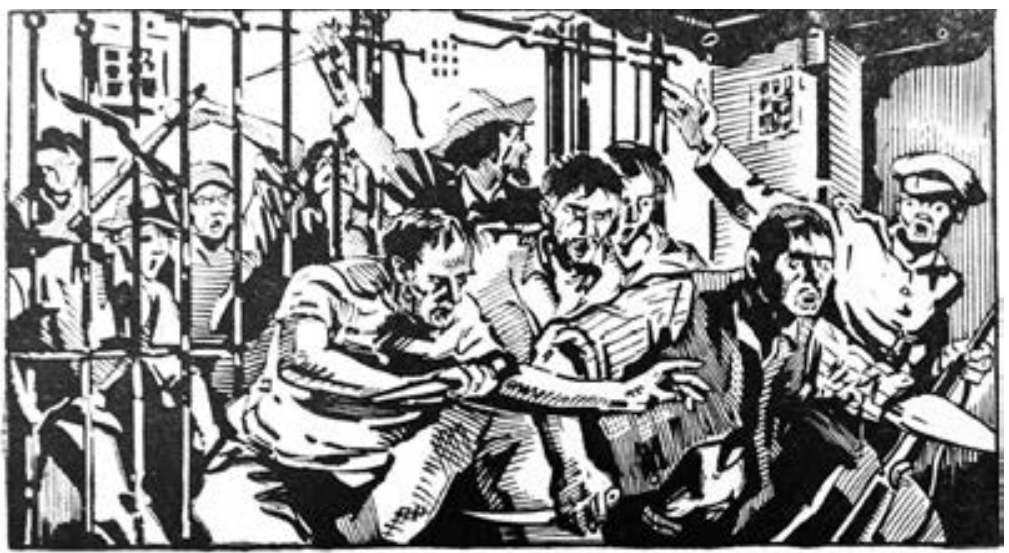

43) Al caer la tarde los criminales revoltosos fuvieron la «jurídicas idea de poner en libertad a sus colegas de presidios y panópticos. 
El aspecto religioso de la historieta no se puede desligar del discurso que le atribuyó a la población revolucionaria. Se le adjudicó la culpabilidad no solo al comunista, sino que además se relacionó a la gente con la denominada alianza atea:

Si el Partido Liberal de Colombia respeta la religión católica y a sus ministros, ¿por qué no ha condenado el saqueo de los templos y el ultraje a las personas consagradas al culto católico? ¿Por qué prefiere que los rectores y maestros de la juventud sean ateos y materialistas? ¿Si el Partido Liberal respeta a la sociedad cristiana, por qué ampara y aparece confundido con el comunismo que la ataca y quiere destruirla? Si es amigo del orden, de la seguridad y tranquilidad de los ciudadanos, si define a la familia, la propiedad y el trabajo creador, ¿por qué protege al comunismo que predica el odio y la lucha de clases? Un partido que en tal forma contraría y desprecia lo que los colombianos amamos y defendemos no puede, sin apelar al engaño y a la mentira, reclamar el apoyo popular para el gobierno del país (José María Villarreal, citado en La gran mancha roja, p. 20).

Los espacios religiosos que se mencionaron en el resumen fueron afectados por el asalto, sin embargo es necesario destacar que en la cita anterior se resalta de manera contundente la relación de la Iglesia con la difusión del "deber ser", y del ciudadano conservador con el "buen cristiano". De esta manera, la Iglesia toma postura frente a lo acontecido y le da legitimidad en las prácticas cristianas a que el accionar de las personas corresponda al de no ser "revoltosas" y, por consiguiente, a hacerse preguntas y a tratar de dar respuestas sobre lo acontecido.

\section{Descripción del 9 de abril y atribución a los responsables}

En el cómic se le atribuye la responsabilidad de la muerte de Gaitán al comunismo, lo cual podría interpretarse como una contradicción ya que en los aspectos analizados se asocia al Partido Liberal con el comunismo. Por ello es difícil pensar en lo que los diferencia o en la 
claridad de la relación de ambos en torno a la culpabilidad del crimen. Sin embargo, es posible analizar que en el cómic se asocia a Gaitán con el comunismo, y al pueblo que hizo la revolución con el Partido Liberal, con quienes cometieron el asalto.

El cómic intenta evidenciar que el Partido Conservador no tuvo ninguna relación con el asesinato de Gaitán, sin embargo estas reiteraciones, junto con las imágenes, muestran que este y la fuerza pública tienen parte de responsabilidad en los hechos, en particular porque con la idea de "mantener el orden" se legitimaban las agresiones a la población.

NO FUERON LOS CONSERVADORES. Y no lo fueron porque el delito aprovecha exclusivamente a los comunistas, en su propósito de sabotear la IX Conferencia, en obedecimiento a órdenes de Moscú. La lógica se impone. ¿Cuál era el único medio de provocar conmoción capaz de acabar con la conferencia? No había sido sino uno solo: la muerte del caudillo que había conquistado justamente el afecto ideológico de las masas bogotanas. El doctor Gaitán había quitado a los comunistas muchos de sus elementos naturales. ¿Qué había que hacer entonces? Suprimir el obstáculo. Y para ello obraron con habilidad diabólica (El Tiempo, 1948, citado en La gran mancha roja, p. 24).

La comunidad internacional apoyó esta afirmación que se reitera a lo largo del cómic. Para ello, cita el texto "La penetración soviética en América”, de Fandiño Silva, en el cual se asocia el asesinato de Gaitán con Rómulo García y la maquinaria del partido prosoviético venezolano.

\section{Respuesta del Estado con la fuerza pública}

En la imagen 82 es posible observar cuando la fuerza pública llega de Boyacá a proteger la república. Asimismo, en las imágenes 41 y 88 se pueden ver que en realidad la revolución fue tímida y que la maquinaria política y militar que puso a disposición el Estado era de gran magnitud y que implicó toda una estrategia para difundir el terror. 
Figura 6. Imágenes 82,41 y 88 de La gran mancha roja, pp. 24, 16 y 25 , respectivamente

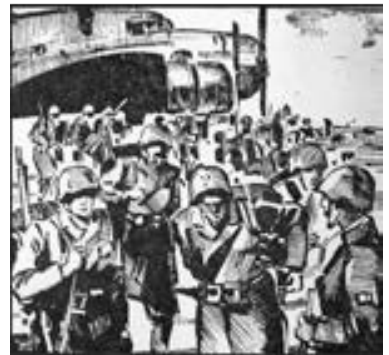

2) Llegabon a tiempo para salver la República.....

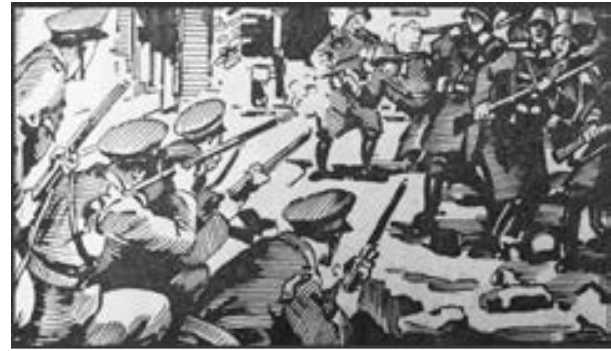

41) Y tenian que limitar su acción inicial a la defonsa del símbolo do la autoridad y a constantes atraves de la Policía insurrecter.

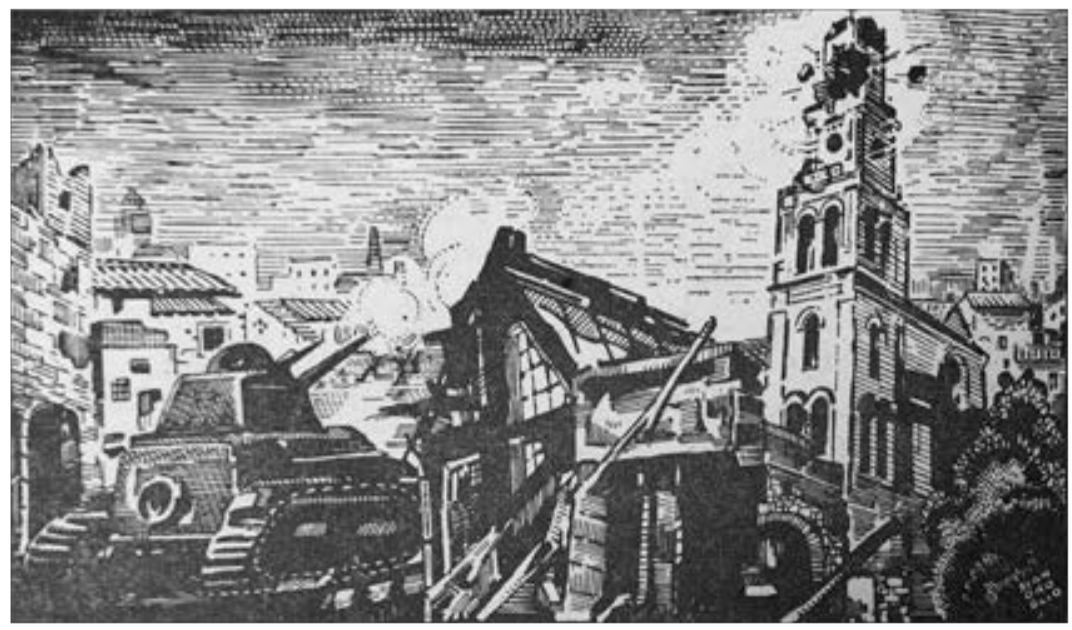

88) Se habian repartido con deliberada estrategia rusa los mejores sitios, y fue necesario batirlos con fuego de cortina como en el caso de la torre de Santa Bárbara, en donde un solo disparo cayeron piedras, ladrillos y comwnistas....

\section{Marino Ospina contra Laureano Gómez}

El discurso de Ospina es transversal en el cómic, su maquinaria política, junto a la Iglesia, instauraron palabras como "las personas de bien”, "los buenos cristianos", "lo popular", "lo populacho", "los revoltosos" y "comunistas", entre otras expresiones, e incluso remarcan la relación del Gobierno con otros países. En uno de los discursos citados en La gran mancha roja, Ospina afirma: 
Jamás una ciudad fue sometida, como Bogotá, al más tremendo sacrificio. Sus edificios, sus monumentos, sus ricas mansiones fueron objeto de una vandálica destrucción que redujo a escombros obras de arte y de belleza, orgullo de la cultura colombiana. Cuanto habíamos construído con inmenso esfuerzo para presentarnos decorosamente ante las naciones amigas, fue bárbaramente aniquilado hasta dejar convertido todo en un hacinamiento de escombros. La historia nacional no conoce una página más vergonzosa de profanación y cobardía (Ospina, citado en La gran mancha roja).

Por otro lado, la alianza militar, la estrategia y el poder se ven de manera directa en las siguientes imágenes de la figura 7 .

Figura 7. Imágenes 55, 56 y 57, La gran mancha roja, p. 19.

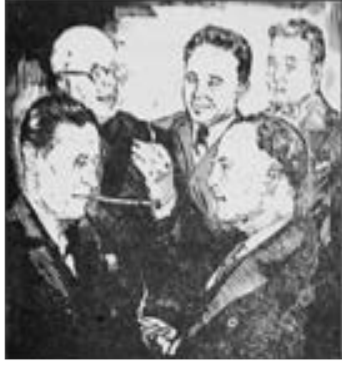

551 Los Ministros del Despache Ejecutive doctores Zuleta Angel, Evaristo Sourdis, toequin Estrada Monsalve, Jose V. Dávile Tollo, José Ma. Bernal, y Lozano y Lozano, to dell Hewtive.

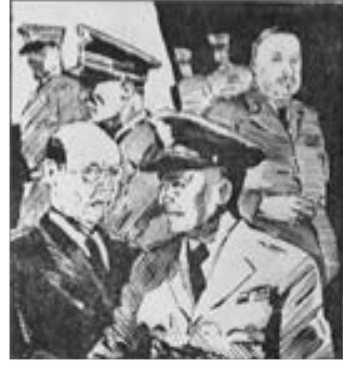

56) Trmbien se hallatian en Palacio las whos Jeres dei Ejercito y entro ellos los Go thez Amaye.

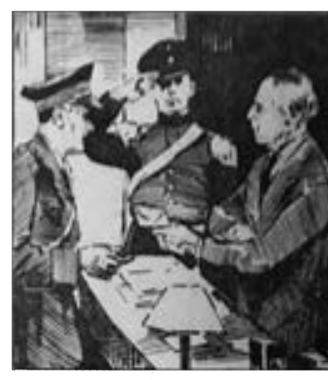

57) Al lade dé los Jefes superieres, lientes y putrietas oficiales del Ejército y suviacion, cumplieron las ordenes dol las Fuerzea Aimadios.

La relación discursiva entre Ospina y Laureano Gómez no aparece de manera directa en el cómic, sin embargo Gómez, al ser el ministro de Relaciones Exteriores, podía tener comunicación internacional y, por ende, difundir los mensajes que se crearan en la Presidencia. Eso lo convertía en un personaje de vital importancia discursiva durante el mandato de Ospina, además era el candidato sucesor y quien, posterior a todos estos hechos, asumió el poder.

La figura de Gómez solo aparece de manera explícita cuando atacan su casa en Torcoroma, cuando los revolucionarios atacan El Siglo por su clara relación con dicho medio de comunicación y cuando observa el saqueo de la ciudad. 
Figura 8. Imágenes 48 y 11.

La gran mancha roja, pp. 17 y 10, respectivamente

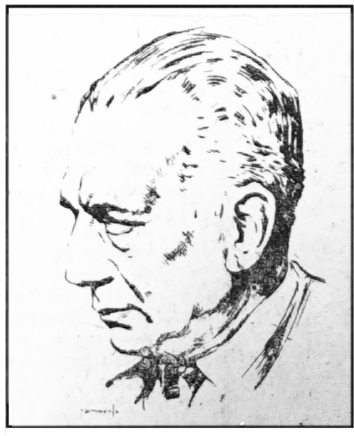

48) Dr. Laureano Gómez. - Al tiempo que los energúmenos de la radio infamaban la República aseverando que ilustres colombianos habian side sacrificados en la plaza de Bolívar.

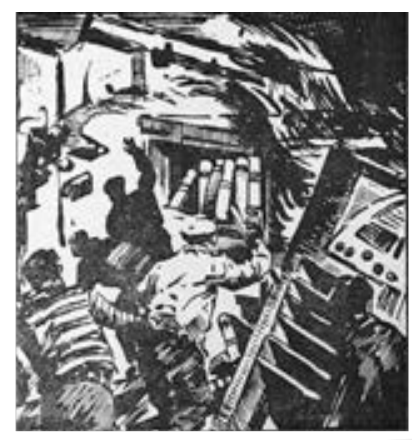

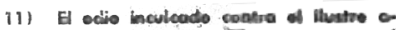

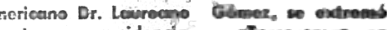

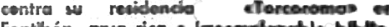

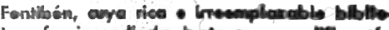

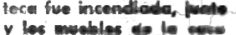

Para concluir, es pertinente destacar que la relación del discurso de la Guerra Fría con la situación política de Colombia se agudizó durante el Bogotazo, y que las lecturas del otro como el enemigo marcaron un importante antecedente histórico para la cultura del país. Este discurso reiterativo necesitó de una maquinaria política que involucró la religión y las fuerzas militares con el postulado de "salvar la patria", para de esta manera incidir en las prácticas con un lenguaje sectario y excluyente. Asimismo, las figuras de Ospina y Gómez fueron muy importantes porque le atribuyeron al liberalismo adjetivos que atentaban contra el orden y la nación.

\section{Análisis de la obra literaria Viento seco}

La obra se ubica en Ceilán, corregimiento cerca de San Rafael, en el Valle de Cauca. En 1950 se había perpetrado una masacre en ese lugar, en la que se configuraron diferentes actores como los pájaros, los chulavitas, los detectives y la Policía. Según El Espectador, la masacre dejó aproximadamente 250 muertos y generó desplazamientos. En un testimonio que recoge Molano, lo describe así:

Cuando parecía que se calmaba la matazón del puente de San Rafael que dejó varios días rojo el río, una tarde se desató un aguacero de balas. De las esquinas del pueblo, del atrio, de la 
torre, del techo de la alcaldía, de todos lados salía plomo. Los vecinos corrían de un lado para otro, la guardia cívica disparó 80 tiros, los que tenían, y todo el mundo echó para el monte. Hasta los tullidos corrían (Molano, 1994, p. 62).

La obra también narra la masacre del 22 de octubre de 1949, perpetrada por los pájaros, los chulavitas y los detectives en la Casa Liberal de Cali, lugar donde se refugiaban los desplazados y familias afectadas por los diversos operativos de dichos grupos.

Cabe resaltar que, a pesar de su gran difusión y recepción, la obra fue controversial, ya que fue una de las primeras en ocuparse de la violencia. Según Bedoya y Escobar en el análisis que le hacen en el texto La novela de la violencia en Colombia: Viento seco de Daniel Caicedo, publicado en 1980, afirman: "Todavía se mantiene el interés por la lectura a pesar de la censura moral y política que tuvo que soportar para mantenerse como documento real, como novela de testimonio de uno de los períodos más nefastos de la historia nacional” (1980, p. 7).

\section{Resumen de la historia}

La historia inicia cuando Antonio Gallardo y su esposa, al hacer el recorrido cotidiano para regresar a casa en la noche, se encuentran con un ataque de los chulavitas en la "torreta", lugar donde la pareja se hallaba. Permanecieron sigilosos, "se distinguían ruidos de maderas rotas, golpes, disparos sordos y explosiones. Y entre ellos una confusión de gritos" (Caicedo, 1953, p. 46). La pareja estaba a solo un kilómetro de su destino, por lo cual, podían oír e intuir lo que acontecía. A pesar del miedo lograron calmarse y seguir su camino. Al llegar a casa la encontraron ardiendo en llamas, pensaban en sus familiares: "los viejos" (padres de Antonio) y su hija.

Gallardo se enfrentó por primera vez a un chulavita mientras su esposa buscaba a los suyos en casa; logró sacar con vida del recinto a la niña, a quien seguramente dieron por muerta los victimarios, según el texto, tras una violación. La pareja se dirigió a la carretera porque "la calle principal de Ceylán estaba llena de detectives y policías uniformados y de civiles con armas" (Caicedo, 1953, p. 54). Tomaron un 
atajo que los conducía a Andalucía y en el camino presenciaron algunos ataques por parte de los pájaros hacia transeúntes y habitantes liberales, ellos siguieron el sendero paralelo al río Bugalagrande y su táctica fue nuevamente ocultarse con su hija, quien muere a causa de las quemaduras que le produjeron una fuerte hemorragia; la entierran cerca de un guayacán florecido.

Continuaron su camino y se encontraron con Pedro, hijo de un conocido, quien había salido al campo cuando fue el asalto. Llegaron a Andalucía, a la casa de Andrés, quien los llevó a Cali. La situación en Andalucía era difícil, los habitantes ya habían empezado a irse para la capital. Andrés atendió a los visitantes, pero ellos, aún impactados con lo acontecido, no quisieron alimentarse.

Emprendieron el viaje al otro día. Después de dos horas y media de trayecto estaban en Juanchito, cerca de un puente sobre el río Cauca. Los detuvieron en un retén de la Policía y fueron sometidos a agresiones. Mientras Pedro y Antonio eran conducidos al jeep en el que se transportaban los uniformados, a Marcela la trasladaron a un cabaret. Entre tanto, Andrés lograba concretar un chantaje con los policías, quienes aceptaron el intercambio de dinero y vieron la posibilidad de seguir extorsionando a Andrés; de esta manera, pudieron llegar a Cali.

Los desplazados se refugiaron en la Casa Liberal mientras que Andrés se hospedó en un hotel cerca. Allí,

Los viajeros recién llegados buscaron desorientados un pequeño espacio vacío entre la multitud. No distinguían a ninguna persona. Todas las personas eran como una sola, enorme, gigantesca con cientos de ojos y de brazos, y de bocas y de piernas, y con una voz confusa, profunda que llenaba el solar y era formada por las voces de todas las bocas (Caicedo, 1953, p. 97).

Una mujer llamada Cristal los orienta, les busca un lugar donde dormir y les proporciona su propia ración de alimento.

Con el paso de los días la situación para la pareja de casados se iba dificultando. Por un lado, Marcela entra en una profunda depresión y por otro, su esposo, en medio de su angustia por Marcela, se enfrenta a la ciudad y sale a trabajar, pero sus esfuerzos son en vano. 
Además, la población liberal tenía que evadir a los carros fantasmas que operaban con autorización del Gobierno y lideraban operaciones para "cazar rojos" mediante la fuerza policial y detectives vestidos de civil y armados.

El 22 de octubre fue un día muy importante en la historia de la novela, ya que el detectivismo se hizo evidente. Mientras los desplazados se encontraban en la Casa Liberal en una conferencia, los carros espías cumplían su labor en los alrededores, y empezó de nuevo la matanza, tanto de transeúntes como de quienes se refugiaban. Dispararon contra la multitud hasta terminar sus balas.

A pesar de las llamadas que se hicieron desde el hospital más cercano del atentado a las autoridades pertinentes, estas no contestaron hasta cuando terminó el ataque. "La Policía ni siquiera se dio por notificada de las llamadas. Todos protegían la retirada de los detectives y mientras tanto los heridos se desangraban" (Caicedo, 1953, p. 115) y el desequilibrio invadió la casa. En esta masacre Antonio fue capturado.

Gallardo fue trasladado a la cárcel, también llamada "el Manicomio". Allí fue arrojado al patio de los calabozos. Los chulavitas lo golpearon en todo el cuerpo hasta que finalmente perdió el conocimiento. El sargento dio la orden de que fuera trasladado a "La Jaula” donde permaneció en este estado y volvió a tener conciencia por unos minutos, pero permanecía inmóvil alrededor de los cadáveres y de sobrevivientes.

En este lugar vivió una serie de maltratos. El autor describe de manera profunda las torturas a que fueron sometidos prisioneros como Gallardo, lo que muestra los modus operandi y las obsesiones de los perpetradores que pasan por coleccionar uñas, castrar a los prisioneros, emplear alambres eléctricos, entre otras formas de violencia que se analizarán en otro apartado.

Posteriormente, los chulavitas llevaron los cuerpos de sus prisioneros hacia las afueras de Cali, se detuvieron en el río y empezaron a arrojarlos allí. Sobre el cuerpo de Gallardo cayó un muerto que ayudó a ocultar que seguía vivo, pues los chulavitas disparaban al agua a la menor sospecha de que alguien siguiera vivo. Antonio luchó contra las adversidades del agua y el viento hasta que tuvo la suerte de encontrarse con Martín, un boga que le salvó la vida y junto con su 
esposa lo cuidó durante dos meses; esto lo hicieron con varios de los moribundos que se encontraban en el río.

Antonio regresó a Cali para buscar el cadáver de su esposa, quien había muerto en el atentado contra los liberales. Gallardo se fue para el cementerio en busca de los muertos del 22 de octubre. Encontró la tumba, una mujer se le acercó y le dio la dirección de Cristal, quien le había encargado esta misión. Él repite la dirección en su mente porque se había borrado el último número de la tumba de Marcela. Logran encontrarse y cuentan sus historias y sus deseos de materializar su venganza, ya que Cristal había sido víctima de la violencia sexual en su pueblo.

Gallardo empieza a materializar su venganza y decide unirse a la guerrilla de Emilio para cobrar la muerte de los suyos, junto a Pablo Ortiz. Llega a Anserma y luego al monte, para unirse a la guerrilla. Por su parte, Cristal también logra vengarse y asesinar a varios policías, para, finalmente, envenenarse junto con sus víctimas.

Antonio, para adherirse a la guerrilla de Emilio, debe pasar por varias pruebas. Llega a tener una confianza especial y pasa a ser el jefe tras el asesinato de Emilio y de Luis, su hermano, pero es traicionado y asesinado por Pedro, detective que ingresó a la guerrilla gracias a la confianza que Antonio le da. Él logra desarticular la guerrilla al asesinar a dos de sus líderes.

\section{Representaciones y actores fundamentales en la novela Viento seco}

Esta novela narra una serie de situaciones complejas que corresponden a la época y que demuestran que el discurso de ese momento estaba acompañado nuevamente por el aspecto religioso y político, evidente en diversas formas de materializar la violencia, en los modus operandi de los victimarios y en los mismos escenarios violentos del Valle del Cauca.

En esta parte nos enfocaremos únicamente en analizar algunas escenas que permiten dejar en evidencia el discurso de lo popular y lo revoltoso, el papel de los medios de comunicación y la maquinaria política de Laureano Gómez, especialmente su relación con la masacre del 22 de octubre y, desde luego, con los victimarios. 
El aspecto discursivo que se planteó anteriormente en torno a la Guerra Fría es posible identificarlo en la novela y de manera directa, por ejemplo: en el momento en que la Policía detiene a Marcela, a Antonio, a don Andrés y a Pedro, don Andrés pregunta por los motivos de la detención y la respuesta es: "Porque ustedes son revoltosos de los que atacaron a las autoridades anoche" (Caicedo, 1953, p. 88).

Otra imagen contundente es la forma como aparecen los medios de comunicación. Antonio expresa su opinión al conversar con otro desplazado en la Casa Liberal: “... Yo que soy una víctima de los asesinos, yo que he perdido cuanto tenía, leo en esos pasquines falangistas que en Ceylán no ha sucedido nada y que 'los pocos' muertos fueron conservadores atacados por liberales revoltosos" (Caicedo, 1953 , p. 88). Posteriormente, hace una crítica que se centra en la desinformación generada por los medios y la censura de la verdad de los hechos. Lo anterior corresponde al apoyo de la violencia a través de la ideología de la Guerra Fría y sus redes de difusión, como los medios de comunicación, los discursos políticos y la Iglesia - aspecto que tomaremos más adelante-. Estas formas de ejercer el poder influyen en los discursos cotidianos y le dan legitimidad al conflicto bipartidista en la novela.

\section{Relación de las masacres con Laureano Gómez}

Las masacres que narra la novela ocurren durante el periodo presidencial de Laureano Gómez. Ya estaban organizados los pájaros y los chulavitas, quienes mediante diversas formas de operar tenían la potestad de asesinar a los liberales, de realizar acciones violentas sobre los cuerpos, las familias, las pertenencias e incluso los animales y, como se evidenció en el resumen de la obra, de infligir las múltiples torturas a las que fue sometida la población liberal. Sin embargo en este apartado nos centraremos en las masacres de Ceilán y la del 22 de octubre. En la primera, Antonio y Marcela tienen que recurrir a diversas tácticas para sobrevivir, como no pasar por las vías principales, sino seguir el río para encontrar una salida segura y posteriormente encontrarse con don Andrés. 
Los victimarios sabían exactamente qué casas atacar, porque habían sido marcadas de rojo; como expresa Pedro: solo se salvaron los godos. Así había pocas posibilidades de fallar. La manera como procedieron en esta masacre fue la quema y destrucción de las casas y de las pertenencias; particularmente a los familiares los amarraron y los dejaron dentro de la casa junto con su hija María José, a quien dieron por muerta. También mataron a Tritón, el perro.

En relación con la masacre del 22 de octubre, es pertinente resaltar que los victimarios actúan de manera conjunta y rápida al dispararle a la multitud de desplazados sin distinción alguna y con ayuda del Estado: un comandante, al parecer del Ejército, y un gobernador (Caicedo, 1953, p. 113). La población no estaba preparada para este ataque, sin embargo

... desde la Clínica Médica que está situada en frente, llamaban a la brigada y al Cuartel. Por estos teléfonos los vecinos pedían a las distintas autoridades locales que vinieran. De la Guardia del Batallón y del Comando anunciaron su inmediata presencia en el lugar, pero no llegaron hasta después del asalto (Caicedo, 1953, p. 115).

De acuerdo con lo anterior, es posible evidenciar que el aparato estatal apoyaba el accionar de los pájaros y los chulavitas, y los detectives podían cometer esta serie de asesinatos y maltratos con la ayuda de las autoridades y con el discurso del enemigo, del comunista y revoltoso, extraído de la Guerra Fría.

Por otro lado, de acuerdo con Escobar y Bedoya, la relación de Laureano Gómez con la masacre del 22 de octubre va más allá de que él era el mandatario de la época, y se fundamenta en un discurso de Lleras Restrepo, quien manifestó que en septiembre de 1949 Ospina se

... entrega irrestrictivamente a la voluntad de Laureano Gómez, hecho que será nefasto para la estabilidad de la "democracia" colombiana. Laureano impondrá, entre otros, al conservador Nicolás Borrero Olano como gobernador del Valle del Cauca. Este gobernará desde el 8 de octubre de 1949 hasta el 12 de mayo de 1950. 
Durante este periodo sucede la masacre de la Casa Liberal en Cali, el 22 de octubre de 1949 (Escobar, 1980, p. 27).

Lo anterior, demuestra que ya había una lectura de Lleras y quizás las de otros políticos que habían identificado el asunto, y además lo ponían en evidencia en sus discursos e incluso en textos. Lleras afirmó en el libro De la república a la dictadura:

Todos los nombramientos son elementos incondicionales del señor Gómez y conocidos por su espíritu violento y sectario... Fueron sus hombres de confianza los agentes de la violencia; él quien inventó la teoría para justificarla... La verdad es que Ospina y Gómez son solidarios de la atroz empresa que condujo al derrumbe de las instituciones y a la desolación de la república (Lleras, citado en Escobar, 1980, p. 27).

\section{Análisis de la obra literaria La metamorfosis de Su Excelencia Descripción de cómo está escrito el texto}

La obra fue publicada en 1963, pero trae una aclaración en la última página: "Se escribió este relato en la ciudad de Bogotá, en los días finales del mes de octubre de 1949, bajo el terror de la época”.

Por otro lado, la obra ha sido comparada con La metamorfosis de Kafka, como un recurso literario empleado para no tocar de manera directa aspectos políticos, aunque es posible establecerlos en su análisis.

\section{Resumen de la historia}

La historia empieza cuando Su Excelencia se levanta del escritorio, finge buscar un libro en la oficina de Fomento y al tener el control del lugar y asegurar una lejanía corporal con el ministro, le dice: “Lo llamaré mañana. Buenas Noches, señor Ministro”. Él responde y se retira. 
Su Excelencia estaba incómodo por un olor putrefacto que emanaba del lugar. Husmeó en la oficina del ministro, pero seguía manifestando corporalmente su malestar, hasta que se acercó a la puerta y localizó el hedor allí en la mitad del despacho presidencial, "en la mesa, en el aire todo, estaba el hedor". Luego, este olor le produjo hipo y un ligero desmayo. Posteriormente, empezó a sufrir una transformación que lo convirtió en una bestia.

Su nariz empezó a cobrar vida propia, podía identificar los sosos olores de los demás políticos como el del ministro de Gobierno y de otros personajes como el del "director de la Policía, del presidente de la Corte, del capellán de palacio”. Asimismo, el mandatario llegó a clasificar los putrefactos olores, pero en últimas todos eran lo mismo: "Un soso olor" que se convirtió en un problema, hasta tal punto que recurrió a proteger su nariz con algodones perfumados.

Con el paso del tiempo sus medidas se agudizaron, ya que no soportaba a los demás, por ello impuso nuevas reglas que implicaban poco contacto corporal. Empezó a pensar en la muerte de los hombres, pero una muerte clasificada por la riqueza y la clase, en ella relacionó primero a la clase alta y luego a los que el autor describe como "los sin nombre".

A menudo Su Excelencia soñaba con imágenes de muerte y lo relacionaba con la religión, aspecto en el cual se profundizará en el análisis. Mientras tanto el hedor se seguía acrecentando y se preguntaba por qué los demás no lo percibían. Llegó un momento en que se cansó y decidió alejarse de las personas a quienes les atribuía ese olor.

De repente Su Excelencia tuvo un espacio de tranquilidad y sintió no solamente otro tipo de olores como el de pino, piñas, piñones y sol, sino que aparecieron sus recuerdos de infancia y le trajeron hasta su despacho el aroma del "pozo azul" que tenía "la más pura y fría agua".

Este olor vuelve a aparecer un día que Su Excelencia se acerca a sus hijos; consternado, tiene pensamientos dolorosos al respecto y busca ir nuevamente al pozo de recuerdos de antaño. Allí reconoció cada parte del lugar, rio y sintió de nuevo la calma. Cuando intentó sumergirse en el agua encontró que el olor soso no solo estaba en su nariz, sino que el agua y el espacio en general también emanaban el 
olor a matadero. De nuevo se desesperó y empezó a gritar. Su chofer y su edecán lo ayudaron a salir de allí.

\section{Análisis de aspectos contundentes de la novela La metamorfosis de Su Excelencia}

La figura de Laureano Gómez es representada en Su Excelencia y evidencia la metamorfosis que sufre el personaje en el inicio de la novela, con el fin de recrear el sarcasmo en el discurso que el exmandatario difundía durante su periodo presidencial.

Laureano quizás combatió por más tiempo y con mayor acritud a los dirigentes de su propio partido que a los del Partido Liberal. Para él, el liberalismo era el basilisco, el monstruo horrendo de pérfido corazón masónico, garras homicidas y pequeña cabeza comunista hambrienta de revolución (El Tiempo, 1999).

Sin embargo el autor se refiere al exmandatario de manera directa solo cuando su olfato se convierte en una preocupación para él: "Las narices de Su Excelencia, las narices presidenciales, comenzaron a convertirse en la única preocupación de Su Excelencia”.

Por otro lado, las descripciones del autor permiten recrear imágenes poéticas que le proporcionan al lector una fina representación del hedor y del pozo. Para ello emplea una narrativa en la que no solo construye frases poéticas, sino que es reiterativo en algunas de ellas, a otras las acentúa en negrita, a otras en negrita y mayúscula sostenida y otras únicamente en mayúscula.

En primera medida, es importante destacar la imagen literaria en la que Su Excelencia sufre la metamorfosis:

Otra vez, el rostro atezado, redondo, macizo, inexpresivo de $\mathrm{Su}$ Excelencia sufrió una metamorfosis de inexplicable encanto: mientras los redondos ojo abiertos no pretendían ver nada, la tensión del cuello, los ágiles movimientos de la cabeza y la rápida palpitación de las aletas de la nariz le rejuvenecían, la prestaban la cándida sorpresa y la sutil inteligencia de una bestia que acabara 
de comunicarse con el mundo misterioso porque el aire le trajo de él, en una invisible brizna de pólen, todo su vibrante paisaje.

En la anterior imagen, Zalamea muestra la metamorfosis como un proceso que tiene doble cara, la de la bestia a la que su nariz se le rejuvenece, y al mismo tiempo contrasta el polen y el paisaje con un párrafo que describe la forma como él empieza a detectar el hedor:

un soso olor a matadero,

Un soso olor a matadero, UN SOSO OLOR A MATADERO' ${ }^{1}$.

Esta expresión se repite constantemente y lo relaciona con "sábanas mancilladas, flores en putrefacción, húmedas cenizas, vendas sanguinolentas... y el tufo extrañamente furruginoso de la cadaveriana”. Su Excelencia no puede controlar lo que sucede con su nariz al identificar este olor tan putrefacto y se lo atribuye en especial a los ministros de Gobierno y de Fomento, y posteriormente a casi todas las personas hasta el punto de tener que ir al pozo azul.

Sin embargo el autor también es contundente cuando afirma que ese "soso olor" pertenece a Su Excelencia y además se cuestiona: “¿Por qué no perciben LOS DEMÁS este hedor?”, y cambia de posición hacia la ventana del despacho:

La abrió. Venteó la noche, alargando el cuello como un gran ciervo herido. Hundió luego la cabeza entre los hombros, inclinándola sobre el pecho para husmearse en sí misma. Y descubrió entonces que el oledero estaba en ella. Ahora comprendía que se ocultaba de sí mismo y que buscaba alejarse de su propio olor.

Otro de los aspectos fundamentales de esta obra es que la muerte y el deseo de esta bestia por matar se hacen evidente en los sueños, recurso que usa el autor en otras formas en las que Su Excelencia expresa

1 Las negritas y mayúsculas de todas las citas del texto analizado corresponden al original. 
sus deseos. Las primeras muertes que empieza a imaginar son las de “... los muertos que por su apellido, casta o riqueza la obligaban a asistir a su entierro; los muertos de su misma clase: de primera clase". La idea de la muerte posteriormente no distinguía clase y comenzó a pensar en que "la muerte del hombre desposeído no acaba en la tumba ni se traslada al otro mundo, sino que se prolonga sobre la tierra, repitiendo su agonía en el hambre de una viuda o contagiando de su miseria al racimo de hijos".

Estas imágenes son una muestra de la época, la muerte en relación con el "soso olor" muestra la violencia bipartidista y la lectura del otro como el "enemigo", el diferente que debe ser exterminado independientemente de su clase. Por ello, cuando Su Excelencia se da cuenta de que él mismo es quien lleva este olor a muerte, entra en un estado que le permite ignorar su culpabilidad, tanto así que se empieza a comparar con Dios, lo que le da a la novela una relación directa con el ser cristiano y además le atribuye al personaje ínfulas de superioridad.

Zalamea evidencia este aspecto después de que narra sus deseos de muerte. En contraste con la imagen del católico ejemplar, nadie sospecharía que estos actos se le atribuyeran, además se justifica la muerte de alguien que atente contra los valores y la moral de la época. Dice la bestia:

Si yo mato a un hombre que se halla en pecado mortal; que puede, además, hallarse en tal estado por la provocación de mi justicia, de mi ira o de mi violencia, no solamente mato su cuerpo sino también su alma, a la que condeno a la perdición eterna, como si yo fuera el propio Dios. De no haberle quitado la vida, ese hombre hubiera tenido tiempo de reparar sus pecados y ganar la bienaventuranza: PERO YO LE TRONCHÉ AQUELLA POSIBILIDAD, LE ROBÉ A ÉL UNA ETERNIDAD DE BEATITUD Y LE ROBÉ AL MISMO DIOS LA OPORTUNIDAD DE SU CLEMENCIA.

Para concluir, entre los aspectos que Jorge Zalamea deja en evidencia en esta obra es posible reconocer la relación del discurso impuesto ante la lectura del "diferente" y la legitimidad que le da la Iglesia para exterminarlo sin importar su condición social. Por otro lado, la metáfora 
del olor fétido y de la bestia le da la vuelta a dicho discurso y pone al lector a relacionar la bestia con el propio discurso de Gómez sobre el comunismo, y no solo representa ser víctima de ello, sino que además deja en evidencia que esa misma bestia tiene momentos de tensión que le producen incertidumbre.

Al mismo tiempo, esta bestia se siente con la capacidad y el deseo, con base en la fe, de matar al igualarse con el estatus de Dios y sin olvidar que es el mandatario del país en ese momento, lo cual le da legitimidad. Finalmente, la historia termina cuando Su Excelencia entra en un estado de desolación al llegar al pozo y reafirmar que él es el maloliente y grita como una bestia. Su chofer y el edecán lo sacan del lugar desnudo, en palabras coloquiales, como cualquier cristiano.

\section{A modo de cierre}

El recorrido de los tres textos que corresponden a este capítulo pone en evidencia que durante 1948 se agudizó la violencia en el país, a lo que contribuyeron varios aspectos políticos. Del análisis del cómic $L a$ gran mancha roja se desprende la clara relación de Gómez y Ospina no solo con el asesinato de Gaitán y las tensiones y poderes que hicieron contraste, sino cómo, mediante un discurso beligerante en contra de los liberales, estos personajes políticos intentaron disminuir y desviar la atención sobre la muerte del caudillo liberal. A esto se sumó la participación en su materialidad de la Iglesia y las fuerzas militares.

Lo anterior contrasta con la novela Viento seco, que muestra a pájaros y chulavitas, quienes están autorizados por el Gobierno para agredir, amenazar y matar a las personas que no están de acuerdo con el Estado. Para este entonces ya Laureano Gómez había tomado el poder. La relación con la masacre del 22 de octubre de 1949 no solo se da por el discurso de Lleras, sino porque no se encontró evidencia de que el Estado se pronunciara al respecto. Por otro lado, se puede inferir que los medios de comunicación son parte vital tanto de la novela como del cómic, ya que sus publicaciones contribuían a reforzar los imaginarios en torno al otro por ser liberal. 
Por último, la novela La metamorfosis de Su Excelencia muestra una imagen de Gómez que muta en la bestia maloliente que él asocia con el comunismo. El mal olor que reconocen sus fosas nasales y que le atribuye a los demás lo lleva a aplicar estrategias para tener el menor contacto posible con lo demás en un principio; posteriormente, se da cuenta de que este hedor proviene de sí mismo. Este soso olor lo lleva a justificar matar al otro por tener faltas de "un buen cristiano", aspecto que se relaciona con la novela Viento seco, ya que muchos de los liberales eran asesinados por ser señalados de protestantes, revoltosos, no buenos ciudadanos o ir en contra de alguna de las normas del Estado.

Escrita en 1949 bajo el terror de la época, la novela reafirma que la vigilancia y el control sobre el liberal, al ser un sujeto diferente, implicaba en definitiva una estrategia estatal que se legitimaba en el discurso de librar la patria de personas indeseables. 
